\title{
Azim Eğitim Programının Azim ve Motivasyonel Kararlılık Düzeylerine Etkisinin İncelenmesi ${ }^{1}$
}

DOI: 10.26466/opus.691887

*

\author{
Nezir Ekinci* - Erdal Hamarta** \\ * Öğr. Gör., Dr., Karamanoğlu Mehmetbey Üniversitesi,Kazım Karabekir MYO,/Karaman/ Türkiye \\ E-Posta: ekincinezir@gmail.com \\ ORCID: 0000-0002-2065-2992 \\ ** Prof. Dr., Necmettin Erbakan Üni., Ahmet Keleşoğlu Eğitim Fakültesi, Meram / Konya/ Türkiye \\ E-Posta: erdalhamarta@gmail.com \\ ORCID: 0000-0003-0925-3824
}

\section{Öz}

$B u$ araştırmanın amacl, ortaöğretim öğrencilerinin azim ve motivasyonel kararlılık düzeylerini artırmaya yönelik hazırlanan psiko-eğitim programının etkisini incelemektir. Araştırmanın çalışma grubunu oluşturmak amacıyla, 2018-2019 eğitim öğretim yılında ortaöğretim kurumunda öğrenim görmekte olan 128 kız, 196 erkek olmak üzere toplam 324 onuncu sinıf öğrencisine Kısa Azim Ölçeği, Motivasyonel Kararlılı Ölçeği ve Kişisel Bilgi Formu uygulanmıştır. Ölçek sonuçları azim ve motivasyonel kararlılık düzeyleri düşük olan, psiko-eğitim programına katılmaya gönüllü ve çalışma grubuna katılım için gerekli ölçütleri să̆layan öğrenciler ile bireysel olarak yapılan görüşmeler sonucunda, 12 öğrenci deney grubuna ve 12 öğrenci kontrol grubuna atanmıştır. Araştırmanın deney grubuna 10 hafta süre ile haftada bir kez olmak üzere azim psiko-eğitim programı uygulanmıştır. Kontrol grubuna herhangi bir işlem yapılmamıştır. Elde edilen verilerin analizinde SPSS 21.0 istatistik programı kullanılarak $t$ testi, tekrarlı ölçümler için ANOVA ve nonparametrik tekniklerden Friedman ve Wilcoxon istatistik analiz teknikleri kullanılmıştır. Araştırmada elde edilen bulgular göre, Azim psiko-eğitim programı, deney grubunda yer alan ortä̈ğretim öğrencilerinin azim ve motivasyonel kararlılı düzeyleri üzerinde anlamlı bir artışa neden olduğu ve psiko-eğitim programının tamamlanmasından 2 ay sonra yapılan izleme ölçümleri arasında anlamlı bir farkın olmadı̆̆ı sonucuna ulaşılmıştır. Araştırma sonuçları ilgili alan yazın kapsamında tartışılmış ve bulgulara dayalı olarak önerilerde bulunulmuştur.

Anahtar Kelimeler: Azim, Motivasyonel Kararllık, Psikoeğitim

\footnotetext{
${ }^{1}$ Bu çalışma Prof. Dr. Erdal HAMARTA danışmanlığında Dr. Nezir EKinCi tarafından hazırlanan Doktora tezinden çıkarılmıştır.
} 


\title{
The Effect of Grit Training Program on Grit and Motivational Stability Levels
}

\begin{abstract}
The purpose of this study is to examine the effect of the psychoeducational program prepared to increase the level of grit and motivational commitment of secondary school students. In order to form the study group of the research, Short Grit Scale, Motivational Stability Scale and Personal Information Form were applied to a total of 324 tenth students, 128 girls and 196 boys studying in the secondary education institution in the 2018-2019 academic year. 12 students were assigned to the experimental group and 12 students to the control group as a result of individual interviews with students whose scale results were low in grit and motivational determination, volunteering to participate in the psycho-education program and providing the necessary criteria for participation in the study group. Grit psycho-education program was applied to the experimental group of the research once a week for 10 weeks. No action was taken on the control group. In the analysis of the data obtained, using the SPSS 21.0 statistical program, $t$ test, ANOVA and nonparametric techniques, Friedman and Wilcoxon statistical analysis techniques were used for repeated measurements. According to the findings obtained in the study, it was concluded that the grit psycho-education program caused a significant increase on the levels of grit and motivational stability of the secondary school students in the experimental group and that there was no significant difference between the monitoring measurements made 2 months after the completion of the psycho-education program. The results of the research were discussed within the scope of the related literature and suggestions were made based on the finding.
\end{abstract}

Keywords: Grit, Motivational Stability, Psychoeducation 


\section{Giriş}

Eğitim toplum içinde yaşayan bireylerin sahip oldukları ve topluma fayda sağlayabilecek yetenek, ilgi, değer, duygu, düşünce, davranışlarını kendi tecrübesi yoluyla fark etme, geliştirme ve değiştirme süreci olarak ifade edilebilir. Eğitim kurumları bir toplumun en önemli ve değerli kurumlarından biridir. Bu kurumların işlevi ve etkinliği toplumu doğrudan etkilemektedir, çünkü eğitim kurumları bir toplumdaki güçlerin ve olanakların dağılımı üzerinde önemli bir etkiye sahiptir ve bireylerin statülerini dikey yönlü ve en hızlı değiştiren faktörlerden biridir (Duman, 2000; Zencirkıran, 2018). Eğitim kurumlarının temel amacı tarih boyunca tartışlan en önemli konulardan biridir. Örgün eğitim kurumlarının tarih boyunca iki temel amacı vardır. Hem akademik becerilerinin geliştirilmesi hem de sosyal ve duygusal becerilerin gelişimini içermektedir. Başka bir ifade ile hem ilgi ve yeteneklerini geliştirerek bir mesleğe hazırlamak hem de önce kendine karşı sorumluluk taşıyan, kendini gerçekleştirme çabası içerisinde olan, daha sonra topluma karşı sorumluluk duyan ve toplumun iyilik haline katkı sunacak nesiller yetiştirmektir (Duckworth, 2006; Hoerr, 2012).

Akademik olarak başarılı olmanın ya da daha zeki olmanın ve iyi olmanın ya da kendine ve topluma karşı sorumlu olmanın iki farklı amaç olduğunun anlaşılmasıyla, eğitimciler okulların vizyonunda, misyonunda ve öğrenme hedeflerinde farklı öğrenci hedeflerini belirleyebilmelidir. Akademik olarak başarılı olan bir öğrenci standart sınavlarda yüksek puanlar alabilen, içerik alanındaki derslerde mükemmel bir performans sergileyen, iyi okuyabilen ve açıkça yazabilen öğrencidir. Diğer yandan, iyi bir öğrenci, kendine ve topluma karşı sorumluluk duyan ve kişisel karakteri ile ailesinde ve toplumunda bir değişim aracı haline gelebilecek kişidir (Gamel, 2014; Lickona, 1991).

Her iki amacın gerçekleşmesi, ideal olana ulaşmak insanın temel istekleri arasındadır. Fakat isteklerimizin gerçekleşmesi için hayaller ile gerçekler arasında köprü vazifesi gören "çaba" gerekmektedir. Hayat çabaladığımızın karşıllğından ibarettir; çabalamadan da başarıya ulaşmak, hayallere, hedeflere ulaşmak mümkündür; fakat çabalayarak ulaşamamak çok zor bir durumdur. Bizim ülkemizde bir parça çaba bile büyük önem taşımaktadır (Baltaş, 2016; Kuzuloğlu, 2019). Eğitimden sanata, ekonomiden siyasete tüm alanlarda yapılan çalışmalara bakıldığı zaman, başarının sürekli bir çaba sonucunda geldiği görülmektedir. İnsanın sorumlu olduğu bir iş ya da görevde 
başarılı olması, kişinin o iş üzerindeki azmi ve kararlılığına bağlı bir durumdur (Baltaş, 2012; Duckworth, 2006, 2016; Sarıçam, Çelik ve Oğuz, 2016).

James (1906), Amerikan Felsefe Birliği'ne yaptığı konuşmasında psikolojinin tüm alanını kapsayacak şekilde özen gösterilebilecek bir çalışma programı önermiştir (James, 1906; akt. Duckworth, 2006). James psikologları iki geniş sorunu ele almaya teşvik etmiştir: birincisi, insan yeteneklerinin türleri neler, ikincisi bireyler bu yetenekleri açığa çıarmada ne çeşit araçlar kullanmaktadır. James'in önerisinden bu yana geçen yüzyılda, psikoloji bilimi bu iki sorunun ilkine cevap vermede etkileyici bir ilerleme kaydetmiştir. Özellikle, zekâ veya genel zihinsel yetenek hakkında çok şey biliyoruz. Zekanın boyut ve kökenleri hakkındaki güçlü tartışmalara rağmen IQ güvenilir ve kesin bir şekilde nasıl ölçüleceği ile ilgili kuramlara sahibiz. Buna karşılık James'in söylediği gibi çoğu kişinin neden kaynaklarının sadece küçük bir kısmını kullandığını ya da bazı istisnai bireylerin ise kendi sınırlarını zorladığı ile ilgili göreceli olarak çok az şey bilinmektedir (Duckworth, 2006).

Eğitim kurumlarında özveri ile çalışan eğitim personelinin, öğretmenlerin, psikolojik danışmanların ve idari personelin temel felsefesi ya da görevi öğrencileri okulda başarıya mı yoksa yaşamda başarıya mı hazırlamalı sorusuna nasıl cevap verileceği neyi ve nasıl öğrettileceğini güçlü bir şekilde etkilemektedir. Çok uzun bir süre boyunca, eğitim çalışanları ve uzmanları yalnızca öğrencileri bir sonraki teste, bir sonraki sınıfa, mezuniyetine, okula vb. için hazırlamaya odaklandılar. Geçilen on yıl boyunca çalıştığımız test puanları yüzdelik dilimler konusunda değerlendirilen öğrenciler, öğretmenler ve okullar sonucunda kısa vadeli odağımızı daha da kötüleştirmektedir (Hoerr,2012). Yüzde 5 ya da 10’luk dilimlere giren öğrenciler, öğretmenler ve okullar eğer başarılı ise daha sınav yapılmadan kesinleşen bir sonuç var. S1nava girecek olan öğrenciler ve onların öğretmenleri ve okullarının yüzde 90 ya da 95'ini başarısız olmaya mahkûm edilmektedir (Selçuk, 2019).

Elbette öğrenciler okulda başarılı olmak için hazırlıklı olmalı; okumayı, yazmayı ve hesaplamayı öğrenmeleri gerekir. Ama bu sadece bir başlangıç olmalıdır. Eğitim çalışanlarının görevi, öğrencileri gerçek dünyada başarıya hazırlamaktır. Yaşamdaki başarıya odaklanmak, okuma, yazma ve hesaplamanın ötesinde, karakter, sosyal ve duygusal zekâ, sorumluluk ve insan çeşitliliğinin karmaşıklığı içinde öğretilmesi anlamına gelir. Ayrıca, azim erdemlerini, dayanıklılık, sebat ve asla vazgeçme yeteneğini de öğretmelidir (Hoerr, 2012). 
Bazı aksaklıklarla karşılaştığında olumlu cevap vermeyi öğrenmek esastır. Akademik performanslarına bakılmaksızın, öğrenciler gerçek dünyadaki sıkıntı ve başarısızlıklarla yüzleşmek zorundadır; herkes er ya da geç bir duvara çarpacak ve başarısızlık ile karşılaşacaktır. Bu hayat içinde insanın deneyimleyeceği olağan bir durumdur. Önemli olan bu durumdan sonra insanın nasıl bir tepki verdiği; duygu, düşünce ve davranışta bulunduğudur (Baltaş, 2012). İşler ters gittiğinde uygun şekilde karşıllk vermek, bir sorunu, engeli öğrendiğimizde, bu başarısızlığı iyi bir başarısızlığa dönüştürmek, yaşamdaki başarının anahtarıdır. Başka bir ifade ile başarısızlık, başarı için gerekli bir durumdur (Baltaş, 2012; Hoerr,2012).

Bu bağlamda öğrencinin akademik başarısına katkıda bulunan ya da daha büyük bir rol oynayabilecek başka faktörler araştırılmaktadır. Artan araştırmalar, sosyal ve duygusal değişkenlerin akademik başarıyla ilgili olduğunu ortaya koymaktadır. Sosyal ve duygusal değişkenlere artan ilgi, bu değişkenlere duyarlı müdahale ve psiko-eğitim programlarının eğitim faaliyetlerinde yer alması, öğrencilerin akademik ve sosyal becerilerinin gelişimi açısından daha faydalı ve etkin olmaktadır (Steinbeck, 2018). İlgili programlar karakter geliştirme eğitimi (Soutter ve Seider, 2013), esneklik programları (PerkinsGough, 2013) ve gelişim odaklı zihniyet programlarını (Dweck, 2010) içermektedir. Sosyal ve duygusal değişkenlere duyarlı müdahale ve psiko-eğitim programlarından biri de "azim" dir (Collaço, 2018; Duckworth, 2016; Fitzgerald ve Lauren-Fitzgerald, 2016; Hochanadel ve Finamore, 2015).

Alan yazında azim kavramin ilk olarak Duckworth (2006), uzun vadeli bir hedefe ulaşmak için gösterilen tutku ve sebat olarak tanımlamıştır. Duckworth azim kavramının bileşenlerini "ilgi", "uygulama", "amaç" ve "umut" olarak belirtmiştir. Yıllar boyunca çaba ve ilgi gösterme eğilimi olan azim, akademik başarının öngörücüsü olan sosyal ve duygusal becerilerden biri olarak göze çarpmaktadır (Kwon, 2018). Ayrıca insanların uzun vadeli hedefler için ilgi ve sebatlarını sürdürdügü bir psikolojik özellik, karakter gücü, sosyal zekâ olarak tanımlanan azim, akademik başarı da dâhil olmak üzere birçok alanda başarı, olumlu duygulanım, mutluluk, umut, ruhsal sorunlara karşı daha dirençli olmak, geleceğe yönelik daha iyimser bakabilme gibi değişkenlerinde bir belirleyicisi olarak tanımlanmıştır (Bogin, 2017; Farroll, 2016; Yoncalık, 2018). 
Azim, okul hayatında ve diğer zorlu gayret gerektiren kişisel, mesleki ve yüksek zorluk dereceli rekabetçi durumlarda öğrenci başarısının iyi bir yordayıcısı olarak ortaya çıkmaktadır (Bogin, 2017; Robinson, 2015; Wallace, 2015). Akademisyenler son zamanlarda California okul bölgelerinden başlayıp ülke çapında yaygınlaşan hatta dünya çapında, azim içeren bir hareket ve ölçütler içerisinde diğer sosyal ve duygusal beceriler dâhil olmak üzere, çocukların azmini geliştirmeye büyük ilgi duymaktadır (Kwon, 2018).

Akademik becerileri akranlarından daha geride, düşük olan öğrenciler uyumlu motivasyonel bir örüntü gösterebilir ve yüksek başarılı bireyler haline gelebilir. Bununla birlikte, akademik becerileri akranlarından ileride, yüksek olan öğrencilerin düşük başarıları olabilir ve akademik hayatları problemli uyumsuz bir duruma gelebilir (Siyez, 2012). Bu nedenle öğrencilerin sahip oldukları azim düzeyleri incelenmeli, azim içeren davranış, düşünce ve duygular onlara fark ettirilmelidir. Öğrencilerin azim düzeylerinin geliştirilmesi için müdahale ve psiko-eğitim programlarına ihtiyaç duyulmaktadır.

Bu bağlamda, özellikle uluslararası alan yazında hem betimsel hem de deneysel çalışmaların ilgi odağı haline gelen azim hakkında bilgi veren psikoeğitim programı anlamlı hale gelmektedir. Bu araştırmada; azim ile ilgili evrensel bilgiler rehberliğinde hayatlarının önemli bir evresinde olan ortaöğretim öğrencilerine yönelik azim farkındalığını oluşturmak ve seviyelerini yükseltmeye yönelik bir psiko-eğitim çalışması ortaya konmaktadır. Bu bilgiler doğrultusunda araştırmanın temel sorusu: azim psiko-eğitim programının lise öğrencilerinin azim ve motivasyonel kararlılık düzeylerinin arttırılmasinda etkili midir? olarak ifade edilmektedir.

\section{Yöntem}

Bu bölümde araştırmanın modeline, araştırma gruplarının oluşturulmasına, veri toplama araçlarına, verilerin değerlendirilmesinde kullanılan yöntemlere, ilişkin bilgilere yer verilmiştir.

\section{Araştırma Modeli}

$\mathrm{Bu}$ araştırma, araştırmacı tarafından hazırlanan Azim Psiko-Eğitim Programı'nın, ortaöğretim öğrencilerinin azim ve motivasyonel kararlılık düzey- 
lerine etkisinin incelendiği yarı deneysel bir çalışmadır. Araştırmanın bağımsız değişkenini azim psiko-eğitim programı, bağımlı değişkenini ise azim ve motivasyonel kararlılık ölçeklerinden hesaplanan azim ve motivasyonel kararlılık puanları oluşturmaktadır.

Öntest-sontest-kontrol ve izleme gruplu yarı deneysel desene göre gerçekleştirilen bu çalışmada bir deney grubu ve bir kontrol grubu oluşturulmuştur. 2x3'lük karışık (split-plot) desen kullanılan bu çalışmada, birinci etmen deneysel işlem gruplarını (deney ve kontrol grupları); ikinci etmen ise bağımlı değişkene ilişkin zamana bağlı tekrarlı ölçümleri (ön-test, son-test ve izleme ölçümleri) göstermektedir (Büyüköztürk, 2002).

Tablo 1. Araştırma Deseni

\begin{tabular}{lllll}
\hline Gruplar & Öntest & İşlem & Sontest & İzleme testi \\
\hline Deney & KAÖ-MKÖ & Azim Psiko-Eğitim Programı & KAÖ-MKÖ & KAÖ-MKÖ \\
\hline Kontrol & KAÖ-MKÖ & $\mathrm{X}$ & KAÖ-MKÖ & KAÖ-MKÖ \\
\hline
\end{tabular}

KAÖ: Kısa Azim Ölçeği ～MKÖ: Motivasyonel Kararlılık Ölçeği

Deneysel araştırmalarda elde edilen sonuçların bir etken ya da etkenler tarafından açıklanabilirliği ve örneklem grubundan daha büyük gruplara genellenebilirliği araştırmacı tarafından dikkat edilmesi gereken önemli konulardan biridir. İç geçerlik deneysel bir çalışmada bağımlı değişkende ortaya çıkan ve gözlemlenen bir farklılığın bağımsız değişkene bağlı olup olmadığıdır. Dış geçerlik ise araştırma sonuçlarının örneklem grubundan daha büyük evrene genellenebilirlik derecesi olarak tanımlanmaktadır (Büyüköztürk ve diğ. 2012).

\section{Araştırma Grubu}

Araştırmanın çalışma grubunu, 2018-2019 Eğitim ve Öğretim yılında Konya ilindeki bir ortaöğretim kurumunda öğrenim görmekte olan 10. sınıf öğrencileri oluşturmaktadır. Araştırma kapsamında azim psiko-eğitim uygulamasının deney ve kontrol gruplarını oluşturmak amacıyla 128 kız, 196 erkek toplam 324 öğrenciye kısa azim ölçeği, motivasyonel kararlılık ölçeği ve kişisel bilgi formu uygulanmıştır.

Araştırmanın çalışma grubunu azim ve motivasyonel kararlılık düzeyleri ortalamanın altında, yüzde 70'lik bölümden, aynı zamanda gönüllü olan ve 
psikiyatrik bir rahatsızlı̆ğ bulunmayan ortaöğretim 10. sınıf öğrencileri oluşturmaktadır.

Tablo 2.Azim Puanı ve Yüzdelik Oranlan

\begin{tabular}{ll}
\hline Yüzdelik & Azim Puanı \\
\hline$\% 10$ & 2.5 \\
\hline$\% 20$ & 3.0 \\
\hline$\% 30$ & 3.3 \\
\hline$\% 40$ & 3.5 \\
\hline$\% 50$ & 3.8 \\
\hline$\% 60$ & 3.9 \\
\hline$\% 70$ & 4.1 \\
\hline$\% 80$ & 4.3 \\
\hline$\% 90$ & 4.5 \\
\hline$\% 95$ & 4.7 \\
\hline$\% 99$ & 4.9 \\
\hline
\end{tabular}

*Örneğin azim puanınız 4.1 çıkarsa, örneklemdeki yetişkinlerin \%70'inden daha azimlisiniz demektir (Duckworth, 2018).

Deneysel araştırma ile yarı deneysel araştırmalar arasındaki en önemli fark; deney ve kontrol gruplarının seçkisiz (yansız) atama tekniği kullanılarak oluşturulmamasından kaynaklanmaktadır. Uygulama alanlarında benzer yaş ve özelliklere sahip çalışma grupları ile araştırmalar yapıldığı için seçkisiz atama tekniği yapılması mümkün olmayabilir. Araştırma, denekler seçkisiz atanamadığından ve çalışma laboratuvar ortamında gerçekleştirilemediğinden dolayı yarı deneysel bir araştırmadır (Bulduk, 2003; Shaughnessy, Zechmeister ve Zechmeister, 2016).

Deney ve kontrol grubunu oluşturan üyelerin sayılarına ait bilgiler aşağıdaki tabloda verilmiştir.

Tablo 3.Deney ve Kontrol Grubu Üye Sayılarn

\begin{tabular}{lllllll}
\hline \multirow{2}{*}{ Gruplar } & \multirow{2}{*}{$\begin{array}{l}\text { Psiko-eğitim grubu başlan- } \\
\text { giç oturumu üye sayısı }\end{array}$} & \multicolumn{2}{c}{ Cinsiyet } & \multicolumn{2}{c}{$\begin{array}{c}\text { Psiko-eğitim grubu sonlan- } \\
\text { dirma oturumu üye sayısı }\end{array}$} & Toplam \\
\cline { 3 - 5 } & 12 & 6 & 6 & 12 & 12 \\
\hline Kontrol & 12 & 6 & 6 & 12 & 12 \\
\hline Toplam & 24 & 12 & 12 & 24 & 24 \\
\hline
\end{tabular}

Tablo 3 incelendiğinde deney ve kontrol grubunda yer alan toplam 24 öğrencinin cinsiyet açısından 12 kadın ve 12 erkekten oluştuğu görülmektedir. 


\section{Veri Toplama Araçları}

Kişisel Bilgi Formu: Araştırmacı tarafından hazırlanan Kişisel Bilgi Formu, ortaöğretim öğrencilerinin cinsiyet, yaş, sınıf, psikiyatrik ilaç kullanımı ve psikiyatri tanı, tedavisi bulunup bulunmadığına ilişkin bilgilerden oluşmaktadır.

Kısa Azim Ölçeği: Kısa Azim Ölçeği Duckworth ve Quinn (2009) tarafından geliştirilmiştir. Ölçeğin orijinal dili İngilizcedir. Türkçe uyarlaması Sarıçam, Çelik ve Oğuz (2016) tarafından yapılan ölçek öz değerlendirmeye yöneliktir. Orijinal kısa azim ölçeği beşli likert olarak geliştirilmiştir. Katılımcılardan (1) Hiç bana göre değil, (2) Çok az bana göre, (3) Biraz bana göre, (4) Oldukça bana göre ve (5) Tam bana göre seçeneklerinden kendilerine en yakın ya da uygun olanı işaretlemeleri araştırmacı tarafından istenmektedir. Uzun azim ölçeği formu 12 maddeden oluşmaktadır. Uzun form ile kısa azim ölçeği formu arasındaki korelasyon katsayısı .91 olduğu için ve ölçeği geliştiren araştırmacı tavsiyesi (Angela Lee Duckworth) üzerine Sarıçam ve diğerleri tarafından ölçeğin kısa formunun uyarlama çalışmasının yapılmasına karar verilmiştir (Sarıçam ve diğ.,2016).

Kısa azim ölçeği, toplam 8 maddeden ve 2 alt boyut; ilginin tutarlılı̆̆ 1 ve gayrette ssrar alt boyutlarından oluşan bir yapıya sahiptir. İlginin tutarlılığ alt boyutu (1.3.5. ve 6.) maddelerinden oluşmakta olup bu maddeler ters kodlanmaktadır. Gayrette israr alt boyutu (2.4.7. ve 8.) maddelerinden oluşmakta olup normal olarak puanlanmaktadır. Ölçekten alınan yüksek toplam azim puanı, yüksek düzeyde azimi ifade etmektedir.

Kısa azim ölçeğinin uyarlama çalışmasında ilk olarak Türkçe çevirisi yapılmıştır. Çeviri her iki dile hâkim iki İngilizce uzmanı tarafından gerçekleştirilmiştir. Daha sonra hem İngilizce hem de Türkçe seviyesi ileri düzeyde olan 29 katılımcı İngilizce ve Türkçe kısa azim ölçeğini doldurmuştur. Ölçeğin dilsel eşdeğerlik çalışması 2 hafta arayla sürmüştür. Dilsel eşdeğerlik sonuçları Türkçe ve İngilizce formlar arasında $r=.89(p=.00)$ olarak bulunmuştur.

Dilsel eşdeğerlik çalışmasından sonra yapı ve benzer ölçek geçerliği çalışması yapılmıştır. Açıklayıcı faktör analizinde ilk olarak çalışma grubunun sayısı ve uygunluğuna bakılmıştır. Çalışma grubu uygunluk katsayısı .83 ve Bartlett Sphericity testi $\chi 2=503,877(p<.001$, sd=24) sonuçları ile çalışma grubu 
sayısının ve uygunluğunun yeterli olduğu tespit edildikten sonra analiz gerçekleştirilmiştir. Açıklayıcı faktör analizi sonucu kısa azim ölçeği maddelerinin orijinal formda olduğu gibi iki faktör altında toplandığı görülmüştür. İlginin tutarlılığ 1 alt boyutu için .46 ile .65 arasında, gayrette ssrar alt boyutu için .67 ile .80 arasında sıralanmaktadır. Bununla birlikte iki alt boyut toplam varyansın \%53'ünü açıkladığı sonucuna varılmıştır. Bir diğer yapı geçerliği çalışmasında doğrulayıc faktör analizi sonucu 2 boyutlu modelin uyum indeksi değerleri $(\chi 2(19, \mathrm{~N}=1,554)=188.52, \mathrm{p}<.001$; RMSEA $=.076(90 \% \mathrm{CI}=$ $.066-.086), C F I=.96)$ olarak bulunmuştur. Ölçeğin faktör yükleri. 37 ile .80 arasında sıralanmaktadır. Ayrıca benzer ölçek geçerliliği çalışmasında kısa azim ölçeği ile motivasyonel kararlılık ölçeği arasında $r=.68$, p<.01 önem düzeyinde ilişki bulunmuştur (Sarıçam ve diğ.,2016).

Ölçeğin güvenirlik çalışmasında Cronbach alfa iç tutarlık güvenirlik katsayıları ilginin tutarlılığı alt boyutu için .80 iken gayrette ssrar alt boyutu için. 71 , olarak tespit edilmiştir. Cronbach alfa iç tutarlık güvenirlik katsayısı ölçeğin tamamı için .82 olarak bulunmuştur. Madde analizi çalışmasında düzeltilmiş madde korelasyon katsayılarının .33 ile .65 arasında sıralandığı bulunmuştur. Özet olarak Kısa Azim Ölçeğinin bireylerde azim, kararlılık, ilgide israr (tutku) ve sebat (çaba) etme düzeyini ortaya çkarabilecek geçerli ve güvenilir bir ölçme aracı olduğu ifade edilebilir (Sarıçam ve diğ.,2016).

Motivasyonel Kararlılık Ölçeği: Motivasyonel Kararlılık Ölçeği Constantin, Holman ve Hojbotă (2011) tarafından geliştirilmiştir. Motivasyonel Kararlılık Ölçeğinin Türkçe uyarlaması Sarıçam, Akın, Ü. Akın ve İlbay (2013) tarafından yapılmıştır. Ölçeğin orijinal formu 13 madde ve 3 alt boyuttan oluşmaktadır. Uzun vadeli hedefleri takip alt boyutu (2.5.8. ve 11.) madde mevcut hedefleri takip alt boyutu (3.6.9. ve 12.) madde ve ulaşllamayan hedefleri yineleme alt boyutu (1.4.7.10. ve 13.) maddelerinden oluşmakta olup, ölçekte ters kodlanan madde bulunmamaktadır. Ölçekten alınan yüksek toplam motivasyonel kararlılık puanı, yüksek düzeyde motivasyonel kararlılı̆̆ı ifade etmektedir.

Motivasyonel kararlılık ölçeğinin uyarlama çalışmasında ilk olarak Türkçe çevirisi yapılmıştır. Çeviri her iki dile hâkim üç İngilizce uzmanı tarafından gerçekleştirilmiştir. Daha sonra hem İngilizce hem de Türkçe seviyesi ileri düzeyde olan 36 İngilizce hazırlık sınıfı öğrencisine İngilizce ve Türkçe 
motivasyonel kararlılık ölçeği uygulanmıştır. Ölçeğin dilsel eşdeğerlik çalışması 2 hafta arayla sürmüştür. Dilsel eşdeğerlik sonuçları Türkçe ve İngilizce formlar arasinda uzun vadeli hedefleri takip alt boyutu $r=.81$, mevcut hedefleri takip alt boyutu $\mathrm{r}=.79$, ve ulaşlamayan hedefleri yineleme alt boyutu $\mathrm{r}=.80$ olarak bulunmuştur. Dilsel eşdeğerlik sonucu ölçeğin tamamı için ise $\mathrm{r}=.88$ olarak tespit edilmiştir.

Dilsel eşdeğerlik çalışmasından sonra yapı ve benzer ölçek geçerliği çalışması yapılmıştır. Açıklayıı faktör analizinde ilk olarak çalışma grubunun sayısı ve uygunluğuna bakılmıştır. Çalışma grubu uygunluk katsayısı .87 ve Bartlett Sphericity testi $\chi 2$ değeri 611.798 ( $\mathrm{p}<.001$, sd=78) bulunmuştur. Açılayıcı faktör analizi sonucu motivasyonel kararlılık ölçeği maddelerinin orijinal formda olduğu gibi üç faktör altında toplandığı görülmüsstür. Açıklayıcı faktör analizi sonucu kısa azim ölçeği maddelerinin orijinal formda olduğu gibi iki faktör altında toplandığı görülmüştür. Açıklayıcı faktör analizi sonucu kısa azim ölçeği maddelerinin orijinal formda olduğu gibi iki faktör altında toplandığı görülmüştür. Temel bileşenler tekniği ile oblik döndürme tekniği kullanılarak elde edilen bulgulara göre; uzun vadeli hedefleri takip alt boyutu için toplam varyansın \%19,44'ünü, mevcut hedefleri takip alt boyutu için toplam varyansın $\% 20,17$ 'sini ve ulaşılamayan hedefleri yineleme alt boyutu için toplam varyansın \%23,70'ini açıkladığı sonucuna varılmıştır. Bir diğer yapı geçerliği çalışmasında doğrulayıcı faktör analizi sonucu 3 boyutlu modelin uyum indeksi değerleri $(\chi 2=141.85, \mathrm{sd}=60, \mathrm{RMSEA}=.058$, $\mathrm{CFI}=.85, \mathrm{GFI}=.95, \mathrm{AGFI}=.92$, SRMR=.057) olarak bulunmuştur. Ölçeğin faktör yükleri .30 ile .61 arasında sıralanmaktadır. Ayrıca benzer ölçek geçerliliği çalışmasında motivasyonel kararlılık ölçeği ile bütünleyici umut ölçeği arasında pozitif ( $r=.41$ ) ilişki olduğu saptanmıştır (Sarıçam ve diğ.,2013).

Ölçeğin güvenirlik çalışmasında Cronbach alfa iç tutarlık güvenirlik katsayıları uzun vadeli hedefleri takip alt boyutu için .72, mevcut hedefleri takip alt boyutu için. 70, ve ulaşlamayan hedefleri yineleme alt boyutu için .71 olarak tespit edilmiştir. Cronbach alfa iç tutarlık güvenirlik katsayısı ölçeğin tamamı için .69 olarak bulunmuştur. Madde analizi çalışmasında düzeltilmiş madde korelasyon katsayılarının .31 ile .56 arasında sıralandığı sonucuna ulaşılmıştır. Özet olarak Motivasyonel Kararlılık Ölçeğinin bireylerde motivasyonel kararlılık düzeylerini ortaya çıarabilecek geçerli ve güvenilir bir ölçme aracı olduğu ifade edilebilir (Sarıçam ve diğ.,2013). 


\section{Ön Ölçüm Puanlarnnn Analiz Sonuçlarn}

Verilerin analizi sürecinde ilk olarak kısa azim ölçeği ve motivasyonel kararlılık ölçeği puanlarının parametrik testlerin varsayımlarını karşılayıp karşılamadığını belirlemek için homejenlik testi ve normallik testleri yapılmıştır.

Tablo 4.Grupların Kısa Azim Ölçeği Ön Ölçüm Puanlarının Dağılımına İlişkin Analiz Sonuçları

\begin{tabular}{|c|c|c|c|c|c|c|c|}
\hline \multirow{2}{*}{$\begin{array}{l}\text { GRUPLAR } \\
\text { Deney }\end{array}$} & \multirow{2}{*}{$\begin{array}{c}\text { Ort } \\
25.00\end{array}$} & \multirow{2}{*}{$\begin{array}{l}\text { Ss } \\
4.11\end{array}$} & \multirow{2}{*}{$\begin{array}{l}\text { Ortanca } \\
26.00\end{array}$} & \multirow{2}{*}{$\begin{array}{l}\text { Çarpıklık } \\
\text { (Skewness) } \\
-.32\end{array}$} & \multirow{2}{*}{$\begin{array}{l}\begin{array}{l}\text { Basıklık } \\
\text { (Kurtosis) }\end{array} \\
-.54\end{array}$} & \multicolumn{2}{|c|}{$\begin{array}{l}\text { Shapiro-Wilk } \\
\text { İstatistik p }\end{array}$} \\
\hline & & & & & & .92 & .29 \\
\hline Kontrol & 24.08 & 4.85 & 24.50 & .19 & $\begin{array}{l}-1.14 \\
\end{array}$ & .92 & .18 \\
\hline
\end{tabular}

Tablo 4 incelendiğinde, deney grubunun kısa azim ölçeği ön test aritmetik ortalaması ile kontrol grubunun ön test aritmetik ortalaması birbirine yakındır. Çarpıklık ve basıklık değerlerinin $7+7+1$ ile -1 arasında olması puanların normalden aşırı bir şekilde sapma göstermediği şeklinde yorumlanabilir. Shipiro- Wilk Testi analiz sonuçları (deney grubu $\mathrm{p}\urcorner 7=.29$, kontrol grubu $\mathrm{p}=.18$, p>.05) anlamlı olmadığından dolayı her bir grubun ön test puanlarının normal dağılım gösterdiği söylenebilir.

Tablo 5. Gruplarnn Kısa Azim Ölçeği Puanlan İçin Levene Hata Varyanslarn Eşitliği Testi Sonuçları

\begin{tabular}{llllll}
\hline \multirow{3}{*}{ Azim Toplam } & Ölçümler & $\mathbf{F}$ & $\mathbf{d f 1}$ & $\mathbf{d f 2}$ & $\mathbf{p}$ \\
\cline { 2 - 6 } & Ön Test & .67 & 1 & 22 & .42 \\
\cline { 2 - 6 } & Son Test & 1.07 & 1 & 22 & .32 \\
\cline { 2 - 5 } & İzleme Test & .26 & 1 & 22 & .61 \\
\hline
\end{tabular}

Tablo 5 incelendiğinde p değerlerinin kısa azim ölçeği toplam puanları için de .05 'ten büyük olduğu görülmektedir. Bu analiz sonucuna göre grupların elde edilen puanlarının varyansları arasında bir fark olmadığı ve varyansların eşitliği koşulunun sağlandığı söylenebilir.

Tablo 6. Gruplarn Azim Toplam Puanlan Box's Kovaryans Matrislerinin Eşitlik Testi Değerleri

\begin{tabular}{llllll}
\hline & Box's M & F & df1 & df2 & p \\
\hline Azim Toplam & 8.55 & 1.21 & 6 & 3506.72 & .29 \\
\hline
\end{tabular}


Tablo 6 incelendiğinde, tekrarlı ölçümlerin koşullarından biri olan ölçüm gruplarının ikili kombinasyonları için grupların kovaryansları arasında anlamlı fark olmamasıdır. Box's Kovaryans Matrislerinin Eşitlik Testi analiz sonucuna göre ( $\mathrm{p}>$.05) anlamlı olmadığından dolayı "her bir grubun kovaryansları arasında anlamlı bir fark yoktur" şeklinde yorumlanabilir.

Tablo 7. Gruplarnn Motivasyonel Kararlılık Ölçeği Ön Ölçüm Puanlarının Dağılımına İlişkin Analiz Sonuçlarn

\begin{tabular}{lcccllccc}
\hline GRUPLAR & Ort & Ss & Ortanca & $\begin{array}{l}\text { Carpıklık } \\
\text { (Skewness) }\end{array}$ & \multicolumn{2}{l}{$\begin{array}{l}\text { Basılklk } \\
\text { (Kurtosis) }\end{array}$} & \multicolumn{2}{c}{ Shapiro-Wilk } \\
\cline { 7 - 9 } & & & & İstatistik & p \\
\hline Deney & 37.83 & 7.29 & 39.50 & -.92 &. & .90 & .18 \\
\hline Kontrol & 36.17 & 7.54 & 36.50 & .09 & -.35 & .97 & .92 \\
\hline
\end{tabular}

Tablo 7 incelendiğinde deney grubunun motivasyonel kararlılık ölçeği ön test aritmetik ortalaması ile kontrol grubunun motivasyonel kararlılık ölçeği ön test aritmetik ortalaması birbirine yakındır. Çarpıklık ve basıklık değerlerinin $7 r+1$ ile -1 arasında olması puanların normalden aşırı bir şekilde sapma göstermediği şeklinde yorumlanabilir. Shipiro- Wilk Testi analiz sonuçları (deney grubu $\mathrm{p}\urcorner 7=.18$, kontrol grubu $\mathrm{p}=.92, \mathrm{p}>.05$ ) anlamlı olmadığından dolayı her bir grubun ön test puanlarının normal dağılım gösterdiği söylenebilir.

Tablo 8. Gruplarnn Motivasyonel Kararlılık Ölçeği Puanlarn İçin Levene Hata Varyanslan Eşitliği Testi Sonuçları

\begin{tabular}{llllll}
\hline & Ölçümler & F & df1 & df2 & $p$ \\
\hline Motivasyonel Kararlılık Toplam & Ön Test & .03 & 1 & 22 & .87 \\
\hline & Son Test & 2.40 & 1 & 22 & .14 \\
\hline & İzleme Test & 2.22 & 1 & 22 & .15 \\
\hline
\end{tabular}

Tablo 8 incelendiğinde, p değerlerinin motivasyonel kararlılık ölçeği toplam puanları için de .05 'ten büyük olduğu görülmektedir. Bu analiz sonucuna göre grupların elde edilen puanlarının varyansları arasında bir fark olmadığı ve varyansların eşitliği koşulunun sağlandığı söylenebilir.

Tablo 9. Gruplarn Motivasyonel Kararlılk Toplam Puanlan Box's Kovaryans Matrislerinin Eşitlik Testi Değerleri

\begin{tabular}{llllll}
\hline & Box's M & F & df1 & df2 & p \\
\hline Motivasyonel Kararlılık & 42.81 & 6.07 & 6 & 3506.72 & .00 \\
\hline
\end{tabular}


Tablo 9 incelendiğinde, tekrarlı ölçümlerin koşullarından biri olan ölçüm gruplarının ikili kombinasyonları için grupların kovaryansları arasında anlamlı fark olmamasıdır. Box's Kovaryans Matrislerinin Eşitlik Testi analiz sonucuna göre ( $p>05)$ anlamlı olduğundan dolay1 "her bir grubun kovaryansları arasında anlamlı bir fark yoktur" koşulu sağlanamamıştır şeklinde yorumlanabilir. Ayrıca bu koşulun sağlanmamasının test sonucu üzerindeki etki mekanizması da tek yönlü değildir. Çünkü bu test kovaryans matrislerinin farklılığı nedeniyle değil, dağılımın normallikten fazlasıyla sapması nedeniyle de anlamlı sonuçlar verebilir (Field, 2009, akt. Can, 2016). Ancak anlamllık düzeyi 0.001 düzeyine yakın olursa, test sonucu üzerindeki olumsuz etki kabul edilebilirlik sınırlarını aşar. Bu durumda koşullar sağlanamadığ zaman başvurulacak alternatif çok değişkenli testlerden Pillai's Trace kullanılabilir. Araştırmanın 3. denencesini test etmek amacıyla Pillai's Trace ölçütü kullanılmıştır.

Tablo 10. Gruplarnn Kısa Azim Ölç̧ӗi ve Motivasyonel Kararlllkk Ölçeği Puanlarnna İlişkin $t$ Testi Sonuçları

\begin{tabular}{lllllll}
\hline & Gruplar & $\mathbf{N}$ & Ort & $\mathbf{S}$ & $\mathbf{t}$ & $\mathbf{p}$ \\
\hline Kısa Azim Ölçeği & Deney & 12 & 25.00 & 4.11 & .49 & .623 \\
\hline & Kontrol & 12 & 24.08 & 4.85 & & \\
\hline $\begin{array}{l}\text { Motivasyonel } \\
\text { Kararlılık Ölçeği }\end{array}$ & Deney & 12 & 37.83 & 7.29 & .55 & .558 \\
\cline { 2 - 7 } & Kontrol & 12 & 36.17 & 7.54 & & \\
\hline
\end{tabular}

Tablo 10 incelendiğinde, kısa azim ölçeği $(\mathrm{t}=.49$, p= .623,) ve motivasyonel kararlılık ölçeği $(t=.55, \mathrm{p}=.588)$ puanlarına göre deney ve kontrol grupları arasında anlamlı bir fark bulunmamıştır ( $\mathrm{p}>.05)$. Deney ve kontrol grupları azim ve motivasyonel kararlılık düzeyleri açısından denk oldukları söylenebilir.

\section{Bulgular}

Bu bölümde araştırmanın denencelerinin test edilmesi amaciyla yapılan istatistiksel analizlere ve bu analizler sonucu elde edilen bulgulara yer verilmiştir. 
Azim Psiko-Ĕ̆itim Programının Ortä̈̆retim Öğrencilerinin Azim Düzeyleri Üzerindeki Etkisine İlişkin Bulgular

Tablo 11. Deney Grubu ve Kontrol Grubunun Ön, Son ve İzleme Testi Ölçümlerine Göre Kısa Azim Ölçeği Puanlarının Ortalama ve Standart Sapma Değerleri

\begin{tabular}{llllllll}
\hline & \multicolumn{3}{c}{ Deney Grubu } & \multicolumn{3}{c}{ Kontrol Grubu } \\
\cline { 2 - 9 } Älçümler & $\mathbf{N}$ & Ort & Ss & N & Ort & Ss \\
\cline { 2 - 8 } Azim Toplam Puanlanı & On Test & 12 & 25.00 & 4.11 & 12 & 24.08 & 4.85 \\
\cline { 2 - 9 } & Son Test & 12 & 32.08 & 4.96 & 12 & 23.92 & 3.55 \\
\cline { 2 - 8 } & İzleme Testi & 12 & 34.17 & 4.30 & 12 & 25.83 & 4.86 \\
\hline
\end{tabular}

Tablo 11 incelendiğinde, deney grubunun kısa azim ölçeği analiz sonuçlarına göre son-test puanlarının aritmetik ortalaması (Ort=32.08, Ss=4.96), öntest puanlarının aritmetik ortalamasından (Ort=25.00, $\mathrm{Ss}=4.11)$ yüksek olduğu görülmektedir. Kontrol grubunun ise kısa azim ölçeği son-test puanlarını aritmetik ortalaması (Ort=23.92, $\mathrm{Ss}=3.55)$ ile ön-test puanlarının aritmetik ortalaması (Ort=24.08, Ss=4.85) arasındaki farkın düşük olduğu görülmektedir.

Azim psiko-eğitim programının tamamlanmasının ardından yapılan sontest ölçümü puanlarının aritmetik ortalaması ile (Ort=32.08, $\mathrm{Ss}=4.96)$ ile 2 ay sonra gerçekleştirilen izleme testi puanlarının aritmetik ortalaması (Ort=34.17, $\mathrm{Ss}=4.85)$ ise birbirine yakındır. Bununla birlikte, psiko-eğitim kontrol grubunun kısa azim ölçeği analiz sonuçlarına göre son-test puanlar1nın aritmetik ortalaması (Ort=23.92, Ss=3.55) ile izleme ölçümü puanlarının aritmetik ortalaması (Ort=25.83, Ss=4.86) arasındaki farkın düşük olduğu görülmektedir. Deney ve kontrol gruplarını puan ortalamaları arasında gözlenen farkın anlamlı olup olmadığı tekrarlı ölçümler için İki Faktörlü Varyans Analizi (2x3 Split-Plot ANOVA) ile test edilmiş ve analiz sonuçları toplam puana göre değerlendirilmiştir.

Tablo 12. Mauchly Eş Değerlik Testi Sonuçlan

\begin{tabular}{llllllll}
\hline & & & & & & \multicolumn{2}{c}{ Epsilon Değerleri } \\
\hline $\begin{array}{l}\text { Gruplar } \\
\text { Arası }\end{array}$ & $\mathbf{W}$ & $\mathbf{X}$ & $\mathrm{Sd}$ & $\mathbf{P}$ & $\begin{array}{l}\text { Greenhouse- } \\
\text { Geisser }\end{array}$ & Huynh-Feldt & $\begin{array}{l}\text { Lowerbo- } \\
\text { und }\end{array}$ \\
\hline Ölçüm & .94 & 1.15 & 2 & .56 & .94 & 1.000 & .500 \\
\hline
\end{tabular}


Tablo 12 incelendiğinde, Mauchly Eş Değerlik Testi analiz sonuçlarına göre (W=.94, $\left.\mathrm{X}^{2}(2)=1.15, \mathrm{p}>.05\right)$, küresellik varsayımının sağlandığı görülmektedir. Daha sonra uygulanan azim psiko-eğitim programının etkililiğinin incelenmesi amacıyla ortaöğretim öğrencilerinin Kısa Azim Ölçeği'nden aldıkları ön-test, son-test ve izleme ölçümleri puanları arasında anlamlı bir fakın olup olmadığının anlaşılması için tekrarlı ölçümler gerçekleştirilmiş, sonuçlar tablo $13^{\prime}$ te sunulmuştur.

Tablo 13. Deney Grubu ve Kontrol Grubunun Ön, Son ve İzleme Testi Ölçümlerine Göre Azim Toplam Puanlarının İki Faktörlü Varyans Analizi Sonuçlar

\begin{tabular}{|c|c|c|c|c|c|c|c|}
\hline $\begin{array}{l}\text { Etki } \\
\text { Değeri }\end{array}$ & & $\begin{array}{l}\text { Kareler } \\
\text { Toplamı }\end{array}$ & $\begin{array}{l}\text { Serbestlik } \\
\text { Derecesi }\end{array}$ & $\begin{array}{l}\text { Kareler } \\
\text { Ortalamas1 }\end{array}$ & F & $\mathbf{P}$ & Np2 \\
\hline Ölçüum & $\begin{array}{l}\text { Sphericity } \\
\text { Assumed }\end{array}$ & 366.028 & 2 & 183.014 & 20.398 & .000 & .48 \\
\hline $\begin{array}{l}\text { Ölçüm* } \\
\text { Grup }\end{array}$ & $\begin{array}{l}\text { Sphericity } \\
\text { Assumed }\end{array}$ & 215.194 & 2 & 107.597 & 11.992 & .000 & .35 \\
\hline $\begin{array}{l}\text { Hata } \\
\text { (Ölçüm) }\end{array}$ & $\begin{array}{l}\text { Sphericity } \\
\text { Assumed }\end{array}$ & 394.778 & 44 & 8.972 & & & \\
\hline
\end{tabular}

Tablo 13 incelendiğinde, deney grubuna uygulanan azim psiko-eğitim programının, ortaöğretim öğrencilerinin azim düzeylerini artırmada etkili olduğu ifade edilebilir [F (2-44) $=11.99, \mathrm{p}<0.01, \eta p 2=0.35]$. Bu analiz sonucu deney ve kontrol grupları arasında ölçümler boyunca (öntest, sontest, izleme) azim toplam puanlarında görülen değişimin \%35'i deneysel işlem tarafından açıklanabilmektedir ( $\eta$ p 2=.35). Bu sonuç araştırmanın ilk denencesi olan "azim psiko-eğitim programı, ortaöğretim öğrencilerinin azim düzeylerini artırmaktadır" hipotezini doğrulamaktadır. Tekrarlı ölçümler analizi sonuçlarının anlamlı çıkması nedeniyle ölçüm (öntest, sontest ve izleme testi) sonuçlarında ortaya çıkan farklılığın kaynağının belirlenmesi için Friedman ve Wilcoxon non-parametrik istatistiksel analiz yöntemleri test edilmiştir.

Tablo 14. Friedman Testi Sonuçlarn

\begin{tabular}{lllll}
\hline Ölçüm & Sıra Ortalaması & Ki-Kare & Sd & p \\
\hline Öntest & 1.08 & 16.12 & 2 & $.000^{*}$ \\
\hline Sontest & 2.29 & & & \\
\hline İzleme Testi & 2.63 & & & \\
\hline${ }^{*} \mathrm{p}<.001$ & & &
\end{tabular}


Tablo 14 incelendiğinde, Friedman Testi analiz sonucuna göre ön-test, son-test ve izleme testi ölçümleri arasında anlamlı bir farkın olduğu görülmektedir $\left(\chi^{2}=16.12, p<.001\right)$. Bununla birlikte Friedman testi modülünde anlamlı farkların hangi ölçümler arasında olduğunu ortaya koymak için bir karşılaştırma testi yoktur. Anlamlı farkların kaynağını ortaya koymak için Wilcoxon Testi (ilişkili örneklemler için iki ölçüm sonucunun kıyaslandığı parametrik olmayan test) ile ikili ölçüm karşılaştırmaları yapılabilir (Can, 2016). Bu bağlamda ortaya çıkan farkın kaynağını belirlemek amacıyla Wilcoxon non-parametrik testi gerçekleştirilmiştir. Sonuçlar Tablo 15 'te sunulmaktadır.

Tablo 15. Deney Grubunun Kısa Azim Ölçeği Öntest- Sontest ve Son-test ve İzleme Testi Puanlarının Karşılaştırilması

\begin{tabular}{lllllll}
\hline & Sıralar & $\mathbf{N}$ & $\begin{array}{l}\text { Sıra } \\
\text { Ortalaması }\end{array}$ & $\begin{array}{l}\text { Sıra Ortalamalarının } \\
\text { Toplamı }\end{array}$ & $\mathbf{Z}$ & $\mathbf{p}$ \\
\hline Öntest- & Negatif & 0 & .00 & .00 & -3.07 & $.00^{*}$ \\
Sontest & Pozitif & 12 & 6.50 & 78.00 & & \\
& Eşit & 0 & & & & \\
& Toplam & 12 & & & -1.43 & .15 \\
\hline Sontest- & Negatif & 3 & 5.67 & 17.00 & & \\
İzleme & Pozitif & 8 & 6.13 & 49.00 & & \\
Testi & Eşit & 1 & & & & \\
& Toplam & 12 & & & & \\
& & & & & & \\
\hline
\end{tabular}

${ }^{*} \mathrm{p}<.001$

Tablo 15 incelendiğinde, Wilcoxon İşaretli Sıralar Testi analiz sonucuna göre ön test ve son test ölçüm puanları arasında anlamlı bir farkın olduğu $(\mathrm{Z}=-3.07, \mathrm{p}<0.001)$, bununla beraber son-test ve izleme testi arasında anlamlı bir farkın olmadığı ortaya konmuştur ( $p>0.05$ ). Bu sonuç araştırmanın ikinci denencesi olan "Deney grubundaki ortaöğretim öğrencilerinin azim düzeylerinin azim psiko-eğitimi sonrası yapılan son test ölçümleri ile izleme testi ölçümleri arasında anlamlı bir fark yoktur" denencesinin doğrulandığg görülmektedir. 
Azim Psiko-Ĕ̆itim Programının Ortaöğretim Ö̆̆grencilerinin Motivasyonel Kararlılı Düzeyleri Üzerindeki Etkisine İlişkin Bulgular

Tablo 16. Deney Grubu ve Kontrol Grubunun Ön, Son ve İzleme Testi Ölçümlerine Göre Motivasyonel Kararlılık Ölçeği Puanlarını Ortalama ve Standart Sapma Değerleri

\begin{tabular}{llllllll}
\hline & \multicolumn{3}{c}{ Deney Grubu } & \multicolumn{3}{c}{ Kontrol Grubu } \\
\cline { 2 - 8 } $\begin{array}{l}\text { Motivasyonel } \\
\text { Kararlılık }\end{array}$ & Ölçüler & $\mathbf{N}$ & Ort & Ss & N & Ort & Ss \\
\cline { 2 - 9 } $\begin{array}{l}\text { Toplam } \\
\text { Puanları }\end{array}$ & Ön Test & 12 & 37.83 & 7.29 & 12 & 36.17 & 7.54 \\
\cline { 2 - 9 } & Son Test & 12 & 47.67 & 4.88 & 12 & 37.33 & 7.61 \\
\cline { 2 - 8 } & İzleme & 12 & 47.58 & 6.67 & 12 & 38.17 & 5.20 \\
\hline
\end{tabular}

Tablo 16 incelendiğinde, deney grubunun motivasyonel kararlılık ölçeği analiz sonuçlarına göre son-test puanlarının aritmetik ortalaması (Ort=47.67, $\mathrm{Ss}=4.88$ ), ön-test puanlarının aritmetik ortalamasından (Ort=37.83, $\mathrm{Ss}=7.29$ ) yüksek olduğu görülmektedir. Kontrol grubunun ise kısa azim ölçeği sontest puanlarının aritmetik ortalaması (Ort=37.33, Ss=7.61) ile ön-test puanlar1nın aritmetik ortalaması (Ort=36.17, Ss=7.54) arasındaki farkın düşük olduğu görülmektedir.

Azim psiko-eğitim programının tamamlanmasının ardından yapılan sontest ölçümü puanlarının aritmetik ortalaması ile (Ort=47.67, Ss=4.88) ile 2 ay sonra gerçekleştirilen izleme testi puanlarının aritmetik ortalaması (Ort=47.58, Ss=6.67) ise birbirine yakındır. Bununla birlikte, psiko-eğitim kontrol grubunun motivasyonel kararlılık ölçeği analiz sonuçlarına göre sontest puanlarının aritmetik ortalaması (Ort=37.33, Ss=7.61) ile izleme ölçümü puanlarının aritmetik ortalaması (Ort=38.17, $\mathrm{Ss}=5.20$ ) arasındaki farkın düşük olduğu görülmektedir. Deney ve kontrol grupların puan ortalamaları arasında gözlenen farkın anlamlı olup olmadığı tekrarlı ölçümler için İki Faktörlü Varyans Analizi (2x3 Split-Plot ANOVA) ile test edilmiş ve analiz sonuçları toplam puana göre değerlendirilmiştir.

Tablo 17. Deney Grubu ve Kontrol Grubunun Ön, Son ve İzleme Testi Ölçümlerine Göre Motivasyonel Kararlllk Toplam Puanlarnnın İki Faktörlü Varyans Analizi Sonuçlan

\begin{tabular}{llllllll}
\hline Etki Değeri & & Value & Hypothesis df & Error df & F & P & Np2 \\
\hline Ölçüm & Pillai's Trace & .443 & 2.000 & 21.000 & 8.352 & .002 & .44 \\
\hline $\begin{array}{l}\text { Ölçüm* } \\
\text { Grup }\end{array}$ & Pillai's Trace & & 2.000 & 21.000 & 6.330 & .007 & .38 \\
\hline${ }^{*} \mathrm{p}>.05{ }^{* *} \mathrm{p}>.001$ & & & & & & & \\
\hline
\end{tabular}


Tablo 17 incelendiğinde, deney grubuna uygulanan azim psiko-eğitim programının, ortaöğretim öğrencilerinin motivasyonel kararlılık düzeylerini artırmada etkili olduğu ifade edilebilir [ $p<0.05, \eta p 2=0.38]$. Bu analiz sonucu deney ve kontrol grupları arasında ölçümler boyunca (öntest, sontest, izleme) motivasyonel kararlılık toplam puanlarında görülen değişimin \%38'i deneysel işlem tarafından açıklanabilmektedir ( $\eta$ p 2=.38). Bu sonuç araştırmanın 3. denencesi olan "azim psiko-eğitim programı, ortaöğretim öğrencilerinin motivasyonel kararlılık düzeylerini artırmaktadır" hipotezini doğrulamaktadır. Tekrarlı ölçümler analizi sonuçlarının anlamlı çıkması nedeniyle ölçüm (öntest, sontest ve izleme testi) sonuçlarında ortaya çıan farklılığın kaynağının belirlenmesi için Friedman ve Wilcoxon non-parametrik istatistiksel analiz yöntemleri test edilmiştir.

Tablo 18. Friedman Testi Sonuçlarn

\begin{tabular}{lllll}
\hline Ölçüm & Sıra Ortalamasi & Ki-Kare & Sd & p \\
\hline Öntest & 1.33 & 8.68 & 2 & $.01^{*}$ \\
\hline Sontest & 2.50 & & & \\
\hline İzleme Testi & 2.17 & & & \\
\hline${ }^{*} \mathrm{p}<.05$ & & & &
\end{tabular}

Tablo 18 incelendiğinde, Friedman Testi analiz sonucuna göre ön-test, son-test ve izleme testi ölçümleri arasında anlamlı bir farkın olduğu görülmektedir $\left(\chi^{2}=8.68, \mathrm{p}<.05\right)$. Bununla birlikte Friedman testi modülünde anlamlı farkların hangi ölçümler arasında olduğunu ortaya koymak için bir karşılaştırma testi yoktur. Anlamlı farkların kaynağını ortaya koymak için Wilcoxon Testi (ilişkili örneklemler için iki ölçüm sonucunun kıyaslandığı parametrik olmayan test) ile ikili ölçüm karşılaştırmaları yapılabilir (Can, 2016). Bu bağlamda ortaya çıkan farkın kaynağını belirlemek amacıyla Wilcoxon non-parametrik testi gerçekleştirilmiştir. Sonuçlar Tablo 19'te sunulmaktadır.

Tablo 19. Deney Grubunun Motivasyonel Kararlılı Ölçeği Ön-test Son-test ve İzleme Testi Puanlarının Karşılaştırılması

\begin{tabular}{lllllll}
\hline & Sıralar & $\mathbf{N}$ & Sıra Ortalaması & Sıra Ortalamalarının Toplamı & $\mathbf{Z}$ & $\mathbf{p}$ \\
\hline Öntest- Sontest & Negatif & 1 & 2 & 2 & & \\
& Pozitif & 11 & 6.91 & 76 & -2.91 & $.00^{*}$ \\
& Eşit & 0 & & & & \\
& Toplam & 12 & & & -.28 & .78 \\
\hline Sontets- & Negatif & 7 & 5.07 & 35.50 & & \\
İzleme Testi & Pozitif & 5 & 8.50 & & & \\
& Eşit & 0 & & & & \\
& Toplam & 12 & & & & \\
\hline
\end{tabular}

${ }^{*_{\mathrm{p}}<.001}$ 
Tablo 19 incelendiğinde, Wilcoxon İşaretli Sıralar Testi analiz sonucuna göre ön test ve son test ölçüm puanları arasında anlamlı bir farkın olduğu $(\mathrm{Z}=-2.91, \mathrm{p}<0.001)$, bununla beraber son-test ve izleme testi arasında anlamlı bir farkın olmadığı ortaya konmuştur $(\mathrm{p}>0.05)$. Bu sonuç araştırmanın dördüncü denencesi olan “Deney grubundaki ortaöğretim öğrencilerinin motivasyonel kararlılık düzeylerinin azim psiko-eğitimi sonrası yapılan son test ölçümleri ile izleme testi ölçümleri arasında anlamlı bir fark yoktur" denencesinin doğrulandığg görülmektedir.

\section{Tartışma, Sonuç ve Öneriler}

Bu bölümde ortaöğretim öğrencilerinin azim ve motivasyonel kararlılık düzeylerinin geliştirilmesinde pozitif psikoloji kuramına dayalı hazırlanmış olan azim psiko-eğitim programının etkilerine ait bulguların tartışma, sonuç ve önerilerine yer verilmiştir.

\section{Tartışma}

$\mathrm{Bu}$ araştırmada azim psiko-eğitim programının öğrencilerin azim ve motivasyonel kararlılık düzeyleri üzerindeki etkisi incelenmiştir. Bu bağlamda, araştırmacı tarafından geliştirilen azim psiko-eğitim programı uygulama öncesinde kısa azim ölçeği ve motivasyonel kararlılık ölçeği ortaöğretim öğrencilerine uygulanarak deney ve kontrol grupları oluşturulmuştur. Araştırmacı tarafından psiko-eğitim programı 10 hafta süreyle haftada bir kez olmak üzere ortaöğretim öğrencilerine uygulanmıştır. Psiko-eğitim uygulaması tamamlandıktan sonra son test ve 2 ay sonra izleme ölçümleri yapılmıştır. Elde edilen verilerin analiz sürecinde ön-test, son-test ve izleme çalışmaları ile geliştirilen programın, öğrencilerin azim ve motivasyonel kararlılık düzeyleri üzerindeki etkisi değerlendirilmiştir.

Azim psiko-eğitim programının etkisine yönelik yapılan analizler sonucunda deney grubunda yer alan öğrencilerin ön test ve son test azim toplam puanları arasında istatistiki açıdan anlamlı bir fark olmasına karşın, kontrol grubu öğrencilerinin ön testten aldıkları azim toplam puanları ile son test puanları arasında istatistiki açıdan anlamlı bir farkın olmadığı tespit edilmiştir. 
Bu sonuç ile araştırmanın ilk denencesi olan 'azim psiko-eğitim programı, ortaöğretim öğrencilerinin azim düzeylerini artırmaktadır' ifadesinin doğrulandığını göstermektedir.

Bununla birlikte izleme çalışması verilerinin analizi sonucunda hem deney grubu hem de kontrol grubu son test ve izleme testi azim toplam puanları arasında istatistiksel olarak anlamlı bir farkın olmadığı görülmüştür. Bu sonuç ile araştırmanın ikinci denencesi olan 'deney grubundaki ortaöğretim öğrencilerinin azim düzeylerinin psiko-eğitim sonrası yapılan son test ölçümleri ile izleme testi ölçümleri arasında anlamlı bir fark yoktur' ifadesinin doğrulandığını göstermektedir.

Azim psiko-eğitim programının etkisine yönelik yapılan analizler sonucunda deney grubunda yer alan öğrencilerin ön test ve son test motivasyonel kararlılık toplam puanları arasında istatistiki açıdan anlamlı bir fark olmasına karşın, kontrol grubu öğrencilerinin ön testten aldıkları motivasyonel kararlılık toplam puanları ile son test toplam puanları arasında istatistiki açıdan anlamlı bir farkın olmadığı tespit edilmiştir. Bu sonuç ile araştırmanın üçüncü denencesi olan 'azim psiko-eğitim programı, ortaöğretim öğrencilerinin motivasyonel kararlılık düzeylerini artırmaktadır' ifadesinin doğrulandığını göstermektedir.

Bununla birlikte izleme çalışması verilerinin analizi sonucunda hem deney grubu hem de kontrol grubu son test ve izleme testi motivasyonel kararlılık toplam puanları arasında istatistiksel olarak anlamlı bir farkın olmadığı görülmüştür. Bu sonuç ile araştırmanın son denencesi olan 'deney grubundaki ortaöğretim öğrencilerinin motivasyonel kararlılık düzeylerinin psikoeğitim sonrası yapılan son test ölçümleri ile izleme testi ölçümleri arasında anlamlı bir fark yoktur' ifadesinin doğrulandığını göstermektedir.

$\mathrm{Bu}$ araştırmanın önemli bir sonucu azim psiko-eğitim programı ortaöğretim öğrencilerinin azim düzeylerini artırmış olmasıdır. Alan yazın incelendiği zaman ülkemizde ortaöğretim öğrencilerinin azim düzeylerini artırmaya yönelik deneysel ya da yarı deneysel psiko-eğitim olarak hazırlanan bir çalışmaya ulaşılamamıştır. Bununla birlikte alan yazında ise sınırlı sayıda araştırmaya ulaşılmıştır (Gamel, 2014; Perez, 2015; Steinbeck, 2018). Alan yazında yer alan deneysel ve betimsel çalışmalar ile tartışmaya devam edilecektir.

Gamel (2014), araştırmasında gelişim odaklı zihniyet programının ergenlerin azim ve esneklik düzeyleri üzerine etkisini incelemiştir. Gelişim odaklı zihniyet programının temel amaçları her şeyin mümkün olabileceği, tutku ile 
çalışma, sorumluluk, şükran duyma, başkalarının esenliğine katkı verme düşüncesi ve anın gücünden faydalanma şeklinde sıralanmıştır. Yapılan analiz sonucunda öğrencilerin azim ve esneklik algı düzeylerinde program öncesi ve sonrasına göre anlamlı düzeyde artış olduğu ve azim düzeylerinin cinsiyet değişkenine göre farklılaşmadığı sonucuna varılmıştır. Azim psiko-eğitim programının umut, tutku ile çalışma, önce kendinin sonra başkalarının esenliğine katkıda bulunma amaçları gelişim odaklı zihniyet programı ile benzerlik göstermektedir. Azim psiko-eğitim programı ile gelişim odaklı zihniyet programı hedef kitlesi birbirine benzer gruplardır; her iki programda ergenler, ortaöğretim öğrencileri ile çalışılmıştır. Bununla birlikte araştırma sonuçları program etkisine yönelik olarak öğrencilerin azim seviyelerinin geliştiğini vurgulamaktadır. Bu durumlar; örneklem, amaç ve sonuç benzerliği aç1sından azim psiko-eğitim programını destekler niteliktedir.

Perez (2015), araştırmasında genel not ortalaması 4,00 üzerinden 2,00'ın altında olan üniversite öğrencilerine Azim Etkisi psiko-eğitim programını uygulamıştır. Programın odak noktaları sırası ile dikkat, değer verme, görev yönetimi, sebat, kaygı, başarısızlıktan kaçınma ve belirsizlik kontrolünü içermektedir. Uygulanan psikoeğitim sonrasında deney grubu öğrencilerinin azim puanlarında artış olduğu tespit edilmiştir. Ayrıca araştırmaya katılan öğrencilerin azim seviyeleri arttıkça akademik not ortalamalarının yükseldiği de gözlemlenmiştir. Azim psiko-eğitim programının bilinçli uygulama, tutku ile çalışma, sebat etme ve umut amaçları ile azim etkisi psiko-eğitim programının amaçları benzerlik göstermektedir. Bu durumlar; amaç ve sonuç benzerliği açısından azim psiko-eğitim programını destekler niteliktedir.

Steinbeck (2018), araştırmasında lise özel eğitim öğrencilerine yönelik azim derslerini içeren 10 haftalık bir program uygulamıştır. Program süresince dersler özellikle sebat, esneklik ve motivasyon gibi sosyal ve duygusal becerilerin geliştirilmesini hedeflemiştir. Bu yarı deneysel çalışmanın sonuçları, katılımc öğrencilerin azim seviyesinin 10 haftalık azim eğitimi aldıktan sonra arttığını göstermektedir. Azim psiko-eğitim programının bilinçli uygulama, çaba ve başarı, sebat etme ve umut amaçları ile azim derslerinin amaçları benzerlik göstermektedir. Bu durumlar; amaç ve sonuç benzerliği açısından azim psiko-eğitim programını destekler niteliktedir.

Azim psiko-eğitim programının bilinçli uygulama amacı ile Farroll'un (2016), azim ile bilinçli uygulama değişkenlerinin atletizm öğrencilerinin s1- 
nav başarısı arasında istatistiksel olarak anlamlı bir ilişki olduğunu tespit etmesi uygulanan deneysel çalışmayı destekler niteliktedir. Ayrıca iki değişkenli (azim ve bilinçli uygulama) kombinasyon analizi, sınav sonuçlarının \%91,3'ünde doğru bir şekilde tahmin ettiği sonucuna varmıştır. Bir diğer araştırmada Duckworth, (2006), azim ile IQ arasında istatistiki açıdan pozitif bir ilişki kurmamakta, daha zeki bireylerin mutlaka daha uzun süre çalışmadıklarını ve hedeflerine yönelik daha fazla çalışma yapmadıkları sonucuna ulaşmaktadır. Araştırmalar sonucunda, bu bulgular son derece zor hedeflere ulaşılmasının sadece yetenek ile değil, aynı zamanda yeteneklerin zaman içinde sürekli ve odaklanmış bir şekilde bilinçli uygulanmasını, çaba gerektirdiğini ortaya koymaktadır. Bu bulgular, akademik başarının yüksek azim seviyesi ile ilişkili olduğunu göstermektedir. Sonuç olarak öğrencilerin akademik çalışmalarında bilinçli uygulama tekniğini kullanmaları ve azim seviyeleri performanslarını olumlu olarak geliştirdiği şeklinde ifade edilebilir.

Azim psiko-eğitim programının umut amacı ile Çelik ve Sarıçam (2018), ve Ekinci ve Hamarta'nın (2019), Singh ve Jha (2008), Yoncalık (2018), araştırmalarında azim ile mutluluk, olumlu duygulanım ve düşünme becerileri arasında istatistiksel olarak pozitif düzeyde anlamlı ilişkiyi tespit etmesi uygulanan deneysel çalışmayı destekler niteliktedir. Diğer taraftan azim ile depresyon, stres, anksiyete, olumsuz yaşantılar ve intihar düşüncesi (Blalock, Young ve Kleiman, 2015; Özhan ve Boyacı, 2018) gibi değişkenler arasındaki istatistiksel olarak negatif düzeyde anlamlı bir ilişkinin olduğunun tespit edilmesi, umut etme becerilerin geliştirilmesinin önemini ortaya koymaktadır. Sonuç olarak öğrencilerin umut etme becerilerin geliştirilmesi, azim seviyelerine olumlu katkı sağladığı şeklinde ifade edilebilir.

Azim psiko-eğitim programının sebat etme ve ilgilerin farkında olma, onları geliştirme ve derinleştirme amacı ile Collaço'nun (2018), azim hakkında gerçekten ne biliniyor sorusuna araştırmasında cevap olarak; azimin yapı geçerliliği birinci olarak sebat ve ilgi tutarlılığından oluşan iki faktörlü yapı, ikinci olarak hedefe ulaşma, odaklanma ve sebattan oluşan üç faktörlü yapı, üçüncü olarak sebat (çaba), ilgi tutarlılı̆̆ı, uyumlu tutku ve obsesif tutkudan oluşan dört faktörlü yapı, dördüncü olarak ise kararlılık ve tutkudan oluşan iki faktörlü yapı sonucu psiko-eğitim uygulamasını destekler niteliktedir. Azimin yapı geçerliliği bulguları ile azim psiko-eğitim programının amaçları benzerlik göstermekte olup, psiko-eğitim uygulama çalışması için önemli niteliktedir. 
Azim psiko-eğitim programının tutku amacı ile Robertson-Kraft ve Duckworth'un (2014) stajyer öğretmenlerin azim düzeyleri ile okulda gösterdikleri performanslarının yükselmesi, öğretmenlik mesleğine devam etme düşüncelerine ve mesleklerine yönelik olumlu bir tutuma sahip olmaları sonucu uygulanan deneysel çalışmayı destekler niteliktedir. Azimin bileşenleri arasında yer alan ve hazırlanan psiko-eğitim programının temel amaçları içerisinde olan tutku, bireylerin faaliyet alanlarında gösterdikleri performanslarını ve tutumlarını pozitif anlamda etkilediği anlaşılmakta olup, azim psikoeğitim çalışmasını destekler niteliktedir.

$\mathrm{Bu}$ araştırmanın önemli bir diğer sonucu azim psiko-eğitim programı ortaöğretim öğrencilerinin motivasyonel kararlılık düzeylerini artırmış olmasıdır. Alan yazın incelendiği zaman ortaöğretim öğrencilerinin motivasyonel kararlılık düzeylerini artırmaya yönelik deneysel ya da yarı deneysel psikoeğitim olarak hazırlanan bir çalışmaya ulaşılamamıştır. Bununla birlikte alan yazında ise sınırlı sayıda azim ve motivasyonel kararlılıkla ilgili betimsel araştırmaya ulaşılmıştır (Boatmun, 2016; Collaço, 2018; Ekinci, Yılmaz ve Hamarta, 2018; Sarıçam, 2015; Wallece, 2015;). Alan yazında yer alan betimsel çalışmalar ile tartışmaya devam edilecektir.

Azim psiko-eğitim programının ortaöğretim öğrencilerinin hem azim seviyelerini hem de motivasyonel kararlılık düzeylerini artırması sonucu alan yazında farklı çalışmalar ile benzerlik göstermektedir. Wallece'ın (2015), araştırmasında geleneksel olmayan teknik lise ile geleneksel lise öğrencilerinin azim düzeyleri arasında fark olup olmadığın incelemiştir. Geleneksel olmayan liseye devam eden öğrencilerin ve geleneksel liseye devam eden öğrencilerin istatistiki olarak farklı bir azim seviyesine sahip olmadığı sonucu bulunmuştur. Bununla birlikte araştırma sonucunda üç ortak tema oluştuğu tespit edilmiştir. İlk tema sebat ve öz motivasyona dayanan bir azim tanımı olduğu, ikinci tema, yetişkinlerin öğrencilerinin yararı için azim modellemesi ihtiyacı olduğu ve üçüncü tema, algılanan azimdeki ya da akademik beklentilerdeki cinsiyetler arasındaki bir farkın olmadığı tespit edilmiştir. Bu bağlamda sebat ve öz motivasyona dayalı tema ile uygulanan psiko-eğitim arasında amaç benzerliği açısından benzerlik bulunmaktadır.

Bir diğer araştırmada Boatman (2016), öğrencilerin akademik başarı ile ilişkilerinde umut ve azimin rolünü nasıl tanımladığını incelemiştir. Öğrenciler akademik başarıda umudu ilk olarak bir aydınlanma ya da idrak etme süreci ile başlaması, ikinci tema duygusal destek sağlayan öğretim üyeleri ve 
uzmanlar aracılığıyla umudun güçlendirilmesi, üçüncü tema aile ve okul olanakları ile umudun güçlendirilmesi, dördüncü tema ise umut, hedef odaklı, öz motivasyonlu ve iyimser olarak tanımlanmaktadır. Uygulanan psiko-eğitim programının umut etmenin önemi fark etme, umut etme becerilerini geliştirilmesinin önemini fark etme, sebat, hedef odaklı uygulama yapma amaçları ile benzerlik göstermekte olup azim psiko-eğitim programını destekler niteliktedir.

Alan yazında motivasyonel kararlılık ile akademik kontrol odağı ve yaşamanın anlamı arasında ilişkinin incelendiği çalışmalar bulunmaktadır. Motivasyonel kararlık ile iç akademik kontrol odağ ile ile motivasyonel kararlılık ölçeğinin tüm alt boyutları (uzun vadeli hedefleri takip, mevcut hedefleri takip, ulaşılamayan hedefleri yineleme) arasında pozitif yönde ve anlamlı ilişkiler olduğu tespit edilmiştir (Sarıçam, 2015). Bir diğer araştırmada öğrencilerin motivasyonel kararlılık düzeyleri ile yaşamın anlamı düzeyleri arasında düşük düzeyde anlamlı bir ilişki olduğu sonucu bulunmuştur (Ekinci, Yılmaz ve Hamarta, 2018). İç akademik kontrol odağı azim pisko-eğitim programının bilinçli uygulama amacı ile, yaşamın anlamı ise tutku amacı ile benzerlik göstermekte olup azim psiko-eğitim programı için önemli niteliktedir.

Bir diğer önemli araştırmada Collaço (2018), sorumluluk kavramının okul başarısını bilişsel yetenek ve azim düzeylerinden daha fazla yordadığı sonucuna ulaşmıştır. Bununla birlikte hem azim ve sorumluluk arasında istatistiksel olarak anlamlı ve güçlü bir pozitif ilişki hem de ilgi, öz yeterlilik, kontrol odağı, sorumluluk ve azim değişkenlerinin tümü arasında istatistiksel olarak anlamlı ve çok güçlü pozitif bir ilişki olduğu tespit edilmiştir. Bu çalışmanın sonuçları azimin sadece sorumluluk ve diğer motivasyonel yapılardan ayırt edilemeyeceğini, ayırt etme çabalarının tamamen ortadan kalktığını göstermektedir. Üniversite başarısının baskın belirleyicisi sorumluluktur ve azim etrafındaki popülerlik sadece onun adına olabilir sonucu bulunmuştur. Genel olarak, bu çalışmanın sonuçları azimin sadece sorumluluk ve diğer motivasyonel yapılardan ayırt edilemeyeceği önerisini sunmuştur.

Özet olarak; bu çalışmada elde edilen bulgulardan araştırmacı tarafından geliştirilen pozitif psikoloji temelli azim psiko-eğitim programının ortaöğretim öğrencilerinin azim ve motivasyonel kararlılık düzeylerine pozitif etkisi görülmektedir. Bununla birlikte yurt içi alan yazında ortaöğretim öğrencilerine ya da diğer eğitim kademelerine yönelik benzer bir çalışma bulunmaması çalışmanın önemini artırmaktadır. Bu nedenle uygulanan ve etkinliği 
sınanan azim psiko-eğitim programı rehberlik ve psikolojik danışmanlık alanında ve özellikle uygulama bölümünde önemli bir ihtiyacı karşılayacağı düşünülmektedir.

\section{Sonuç}

Azim psiko-eğitim programı uygulama çalışmasından elde edilen bulgulara dayalı araştırmanın sonuçları aşağıda sıralanmıştır.

1. Azim psiko-eğitim program1, deney grubunda yer alan ortaöğretim öğrencilerinin azim düzeylerini artırmaktadır.

2. Deney grubundaki ortaöğretim öğrencilerinin azim düzeylerinin psikoeğitim sonrası yapılan son test ölçümleri ile izleme testi ölçümleri arasinda anlamlı bir fark yoktur.

3. Azim psiko-eğitim programı, deney grubunda yer alan ortaöğretim öğrencilerinin motivasyonel kararlılık düzeylerini artırmaktadır.

4. Deney grubundaki ortaöğretim öğrencilerinin motivasyonel kararlılık düzeylerinin psiko-eğitim sonrası yapılan son test ölçümleri ile izleme testi ölçümleri arasında anlamlı bir fark yoktur.

Sonuç olarak; pozitif psikoloji temelli hazırlanan azim psiko-eğitim programı ortaöğretim öğrencilerinin azim ve motivasyonel kararlılık düzeylerini artırmaktadır. Programının öğrenciler üzerindeki pozitif etkisi izleme ölçümlerinde görülmektedir.

\section{Öneriler}

Aşağıda azim psiko-eğitim programının etkililiğinin sınandığı bu çalışmadan elde edilen bulgulara dayalı olarak psikolojik danışmanlar ve akademisyenler için alan yazına fayda sağlayabilecek önerilere yer verilmiştir.

Araştırmacılara Yönelik Öneriler:

1. Ortaöğretim öğrencilerinin azim ve motivasyonel kararlılık düzeylerini artırmaya yönelik hazırlanan azim psiko-eğitim programına benzer çalışmalar farklı eğitim kademlerine göre de hazırlanması önerilir. 
2. Ortaöğretim öğrencilerinin azim ve motivasyonel kararlılık düzeylerini artırmaya yönelik hazırlanan azim psiko-eğitim programına benzer çalışmalar özel eğitim öğrencileri için hazırlanması araştırmacı tarafından özellikle önerilir.

3. Türk kültürüne uygun geçerlilik ve güvenirlik çalışması yapılan azim ile ilgili ölçme araçları geliştirilmesi önerilir.

4. Azim kavramının Türk kültürü bağlamında yapı geçerliliği üzerine çok değişkenli istatistiksel analizler yapılarak ne anlam ifade ettiği araştırılabilir.

\section{Uygulamaya Yönelik Öneriler:}

1. Rehberlik ve psikolojik danışmanlık alanında önemi son yıllarda artan psiko-eğitim uygulamalarında, azim temalı programların öğrencilere yönelik hazırlanması ve uygulanması araştırmacı tarafından önerilir.

2. Rehberlik ve psikolojik danışmanlık alanında önemi son yıllarda artan psiko-eğitim uygulamalarında, motivasyonel kararlılık temalı programların öğrencilere yönelik hazırlanması ve uygulanması araştırmacı tarafından önerilir. 


\title{
EXTENDED ABSTRACT
}

\section{The Effect of Grit Training Program on Grit and Motivational Stability Levels}

\author{
Nezir Ekinci- Erdal Hamarta \\ Karamanoğlu Mehmet Bey University, Necmettin Erbakan University
}

Education can be expressed as the process of recognizing, developing and changing the abilities, interests, values, emotions, thoughts, behaviors of individuals living in the society that can benefit society. Educational institutions are one of the most important and valuable institutions of a society. The function and effectiveness of these institutions directly affect the collective, because educational institutions have a significant impact on the distribution of powers and opportunities in a society and are one of the factors that change individuals' status in a vertical and fastest direction (Duman, 2000; Zencirk1ran, 2018). The main purpose of educational institutions is one of the most important issues discussed throughout history. Formal education institutions have two main objectives throughout history. It includes both the development of academic skills and the development of social and emotional skills. In other words, it is to prepare a profession by developing its interests and abilities, as well as to raise generations that are responsible for themselves, are in an effort to realize themselves, then are responsible for the society and will contribute to the well-being of the society (Duckworth, 2006; Hoerr , 2012).

Educators should be able to identify different student goals in the vision, mission and learning goals of schools, with the understanding that being academically successful or being smarter and well-being or being responsible for self and society are two different goals. An academically successful student is a student who can score high on standardized exams, perform perfectly in courses in the content area, can read well and write clearly. On the other hand, a good student is a person who is responsible for himself and the society and can become a tool of change in his family and society with his personal character (Gamel, 2014; Lickona, 1991). 
Increasing research reveals that social and emotional variables are related to academic success. Increasing interest in social and emotional variables, intervention sensitive to these variables, and involvement of psycho-education programs in educational activities are more beneficial and effective for the development of students' academic and social skills (Steinbeck, 2018). Related programs include character development training (Soutter and Seider, 2013), flexibility programs (Perkins-Gough, 2013) and development-oriented mentality programs (Dweck, 2010). One of the intervention and psychoeducational programs sensitive to social and emotional variables is "grit" (Collaço, 2018; Duckworth, 2016; Fitzgerald and Lauren-Fitzgerald, 2016; Hochanadel and Finamore, 2015).

This section includes information about the model of the research, the creation of research groups, data collection tools, the methods used in the evaluation of the data, and related information.

This research is a semi-experimental study examining the effect of the Grit Psycho-Education Program prepared by the researcher on the level of grit and motivational determination of secondary school students. The independent variable of the research is determined by the grit psycho-education program and the dependent variable from the scales of grit and motivational determination and grit and motivational stability scores.

In this study carried out according to the semi-experimental pattern with pretest-posttest-control and monitoring groups, an experimental group and a control group were created. In this study where $2 \times 3$ mixed-plot pattern is used, the first factor is the experimental process groups (experiment and control groups); The second factor shows time-dependent repeated measurements (pre-test, post-test and follow-up measurements) of the dependent variable (Büyüköztürk, 2002).

According to the results of Wilcoxon Signed Ranks Test analysis, it was revealed that there was a significant difference between the pretest and posttest measurement scores $(Z=-3.07, p<0.001)$, however there was no significant difference between the posttest and follow-up test ( $p>0.05$ ). This result is the second study of the study, which shows that the balance between the post-test measurements performed after the grit psycho-education of the perseverance levels of the secondary school students in the experimental group and the follow-up test measurements was confirmed. 
According to the results of Wilcoxon Signed Ranks Test analysis, it was revealed that there was a significant difference between the pretest and posttest measurement scores $(Z=-2.91, p<0.001)$, however, there was no significant difference between the posttest and follow-up test ( $p>0.05)$. This result is the fourth hypothesis of the study, and it seems that the balance between the post-test measurements performed after grit psycho-education and the follow-up test measurements of the secondary school students in the experimental group was confirmed.

The results of the research based on the findings obtained from the grit psycho-education program implementation study are listed below.

1. Grit psycho-education program increases the grit levels of secondary school students in the experimental group.

2. There is no significant difference between the post-test measurements performed after psycho-education and the follow-up test measurements of the grit levels of the secondary school students in the experimental group.

3. Grit psycho-education program increases the motivational commitment levels of secondary school students in the experimental group.

4. There is no significant difference between the post-psychometry post-test measurements and the follow-up test measurements of the motivational stability levels of secondary school students in the experimental group.

As a result; The grit psychoeducational program based on positive psychology increases the level of perseverance and motivational commitment of secondary school students. The positive effect of the program on students can be seen in the monitoring measurements.

Based on the findings obtained from this study, in which the effectiveness of the grit psycho-education program is tested below, suggestions are given for psychological counselors and academicians who may benefit from the literature.

Suggestions for Researchers:

1. It is recommended that studies similar to the grit psychoeducational program prepared to increase the level of grit and motivational commitment of secondary school students should be prepared according to different educational levels.

2. Studies similar to the grit psychoeducational program prepared to increase the level of grit and motivational commitment of secondary 
school students are especially recommended by the researcher to prepare them for special education students.

3. It is recommended to develop measurement tools related to perseverance in which validity and reliability studies are made in accordance with Turkish culture.

4. The meaning of the concept of perseverance can be investigated by means of multivariate statistical analyzes on construct validity in the context of Turkish culture.

\section{Kaynakça / References}

Akın, A., ve Akın, Ü. (2015). Güncel psikolojik kavramlar I: Pozitif psikoloji. 1. Baskı. Ankara: Nobel Akademik Yayınclik.

Arslan, S., Akın, A. ve Çitemel, N. (2013). The predictive role of grit on metacognition in Turkish university students. Studia Psychologica, 55(4), 311-321. https://doi.org/10.21909/sp.2013.04.645

Baltaş, A. (2012). Hayalini yorganına göre uzat. 6. Baskı. İstanbul: Remzi Kitabevi.

Baltaş, A. (2016). Stres altında ve ezilmeden öğrenmede ve stnavlarda üstün başarı. 29 Baskı. İstanbul: Remzi Kitabevi.

Bazelais, P., Lemay, D. J. ve Doleck, T. (2016). How Does grit impact college students' academic achievement in science?. European Journal of Science and Mathematics Education, 4(1), 33-43.

Blalock, D. V., Young, K. C. ve Kleiman, E. M. (2015). Stability amidst turmoil: Grit buffers the effects of negative life events on suicidal ideation. Psychiatry research, 228(3), 781-784. https://doi.org/10.1016/j.psychres.2015.04.041

Boatmun, T. (2016). Hope, grit, and academically successful non-traditional students at a regional, rural university: A narrative inquiry (Order No. 10038708). Available from ProQuest Dissertations \& Theses Global. (1775722631). Retrieved from https://search.proquest.com/docview/1775722631?accountid=159111

Boatmun, T. (2016). Hope, grit, and academically successful non-traditional students at a regional, rural university: A narrative inquiry (Order No. 10038708). Available from ProQuest Dissertations \& Theses Global. (1775722631). Retrieved from https://search.proquest.com/docview/1775722631?accountid=159111

Bogin, L. (2017). A portrait of college success: Grit, theories of intelligence, and cumulative life adversity. ETD Collection for Pace University. AAI10689593. https://digitalcommons.pace.edu/dissertations/AAI10689593

Bulduk, S. (2003). Psikolojide deneysel araştırma yöntemleri. İstanbul: Çantay Yayınclik. 
Büyüköztürk, Ş. (2002). Faktör analizi: Temel kavramlar ve Ölçek Geliştirmede Kullanımı. Eğitim Yönetimi Dergisi, 32, 470-483.

Büyüköztürk, Ş., Kılıç Çakmak, E., Akgün, Ö. E., Karadeniz, Ş., Demirel, F. (2012). Bilimsel araştırma yöntemleri. 12. Baskı, Ankara: Pegem Yayınları.

Can, A. (2016). Spss ile bilimsel araştırma sürecinde nicel veri analizi. 4. Baskı. Ankara: Pegem Akademi Yayınclik.

Collaco, C. M. (2018). What do we really know about grit? A multivariate statistical investigation on the construct validity of grit. Unpublished doctoral dissertation. The University of San Francisco, San Francisco.

Constantın, T., Holman, A., Hojbotă, Ma. (2011). Development and validation of a motivational persistence scale. Psihologija, 45(2), 99-120. https://doi.org/10.2298/PSI1202099C

Duckworth, A. (2018). Azim sabır, tutku ve kararlılı̆̆ın gücü. (Çev. Öyküm Taner). İstanbul: Pegasus Yayıncllik.

Duckworth, A. L. (2006). Intelligence is not enough: Non -IQ predictors of achievement. Dissertations available from ProQuest. AAI3211063. https://repository.upenn.edu/dissertations/AAI3211063

Duckworth, A. L. ve Quinn, P. D. (2009). Development and validation of the short grit scale (Grit-S). Journal of Personality Assessment, 91(2), 166-174. https://doi.org/10.1080/00223890802634290

Duckworth, A. L., Peterson, C., Matthews, M. D. ve Kelly, D. R. (2007). Grit: Perseverance and passion for long-term goals. Journal of Personality and Social Psychology, 92(6), 1087-1101. https://doi.org/10.1037/0022-3514.92.6.1087

Duckworth, A. ve Gross, J. J. (2014). Self-control and grit: related but separable determinants of success. Current directions in psychological science, 23(5), 319325. https://doi.org/10.1177/0963721414541462

Duman, A., (2000), Yetişkinler eğitimi. Ankara: Ütopya Yayınevi.

Dweck, C. S. (2010). Mind-sets and equitable education. Principal Leadership, 10(5), 26- 29.

Ekinci, N., Yılmaz, H. ve Hamarta, E. (2018). Meslek yüksekokulu öğrencilerinin motivasyonel kararlılık düzeyleri ile yaşamın anlamı düzeylerinin incelenmesi. Presented at the III. International Academic Research Congress. 28 Nisan- 1 Mayıs 2018, Alanya/Antalya.

Farroll, J. C. (2016). Grit, deliberate practice, and athletic training education: Factors that determine board of certification exam success (Order No. 10307061). Available from ProQuest Dissertations \& Theses Global. (1873447170). Retrieved from https://search.proquest.com/docview/1873447170?accountid=25089. 
Fitzgerald, C. J. ve Laurian-Fitzgerald, S. (2016). Helping students enhance their grit and growth mindset. Journal Plus Education, 14, 52-67.

Gamel, M. (2014). Impact of character development and empowerment program on grit and resilience growth in early and middle adolescents. Unpublished doctoral dissertation. Kennesaw State University, Georgia.

Hochanadel, A. ve Finamore, D. (2015). Fixed and growth mindset in education and how grit helps students persist in the face of adversity. Journal of International Education Research, 11(1), 47-50. https://doi.org/10.19030/jier.v11i1.9099

Hoerr, T.R. (2012). Fostering grit: how do I prepare my students for the real world? Alexandria. VA: ASCD.

Kuzuloğlu, M. S. (2019). Limonata bardağındaki başarı sırrı. Youtube [VideoBlog] 19.04.2019 tarihinde .https://www.youtube.com/watch?v=KiBAN99KjwM. adresinden erişilmiştr.

Kwon, H. W. (2018). The sociology of grit: Cross-cultural approaches to social stratification (Order No. 10811496). Available from ProQuest Dissertations \& Theses Global. (2115839979). Retrieved from https://search.proquest.com/docview/2115839979?accountid=25089.

Lickona, T. (1997). A comprehensive approach to character building in Catholic Schools. Catholic education. A Journal of Inquiry and Practice, 1(2). Retrieved from https://ejournals.bc.edu/index.php/cej/article/view/22

Özhan, M. B. ve Boyaci, M. (2018). Üniversite öğrencilerinde depresyon, anksiyete ve stresin yordayıcısı olarak azim: bir yapısal eşitlik modellemesi [Grit as a predictor of depression, anxiety and stress among university students: A structural equation modeling]. Anadolu Psikiyatri Dergisi, 19(4), 370-376.

Perez, M. (2015). Obtaining academic success: Nurturing grit in students. Journal of Interpersonal Relations Intergroup Relations and Identity, 8(Hiver/Winter), 56-63.

Perkins-Gough, D. (2013). The significance of grit: A conversation with Angela Lee Duckworth. Educational Leadership, 71(1), 14-20.

Robertson-Kraft, C. ve Duckworth, A. L. (2014). True grit: Trait-level perseverance and passion for long-term goals predicts effectiveness and retention among novice teachers. Teachers College record (1970), 116(3).

Robinson, W. L. (2015). Grit and demographic characteristics associated with nursing student course engagement (Order No. 3718182). Available from ProQuest Dissertations \& Theses Global. (1708647383). Retrieved from https://search.proquest.com/docview/1708647383?accountid=25089. 
Sarıçam, H., Çelik, İ. ve Oğuz, A. (2016). Kısa azim (sebat) ölçeğinin Türkçeye uyarlanması: Geçerlik ve güvenirlik çalışması. Uluslararası Türkçe Edebiyat Kültür Ĕ̆itim Dergisi 2016; 5(2), 927-935. https://doi.org/10.7884/teke.622

Sarıçam, H. (2015). Academic locus of control and motivational persistence: Structural equation modeling [Akademik Kontrol Odağı ve Motivasyonel Kararlılık: Yapısal Eşitlik Modellemesi]. Eğitim Bilimleri Araştırmaları Dergisi- Journal of Educational Sciences Research, 5(1), 79-92. http://ebadjesr.com/

Sarıçam, H., Akın, A., Akın, Ü. ve İlbay, A. B. (2013). Motivasyonel kararlılık ölçeğinin Türkçe formu: Geçerlik ve güvenirlik çalışması. Turkish Journal of Education, 3(1), 60-69. https://doi.org/10.17121/ressjournal.109

Selçuk, Z. (2019). Milli Eğitim Bakanı Ziya Selçuk merak edilen her şeyi 40'ta anlatt. Youtube[VideoBlog] 23.04.2019 tarihinde https://www.youtube.com/watch? $\mathrm{v}=\mathrm{X} 2 \mathrm{AabpoUB} 2 \mathrm{~s}$ adresinden erişilmiştir.

Shaughnessy, J. J., Zechmeister, E.B. ve Zechmeister, J. S. (2016). Psikolojide araştırma yöntemleri. 10. Baskı. (Çev. Ed. İlyas Göz). Ankara: Nobel Akademik Yayıncilik.

Singh, K. ve Jha, S. D. (2008). Positive and negative affect, and grit as predictors of happiness and life satisfaction. Journal of the Indian Academy of Applied Psychology, 34(Spec Issue), 40-45.

Soutter, M. ve Seider, S. (2013). College access, student success, and the new character education. Journal of College and Character, 14(4), 351-356. doi:10.1515/jcc- 2013-0044. https://doi.org/10.1515/jcc-2013-0044

Steinbeck, K. M. (2018). The impact of grit and non-cognitive skills on high school special education student success (Order No. 13423045). Available from ProQuest Dissertations \& Theses Global. (2158870695). Retrieved from https://search.proquest.com/docview/2158870695? accountid=25089.

Steinbeck, K. M. (2018). The impact of grit and non-cognitive skills on high school special education student success (Order No. 13423045). Available from ProQuest Dissertations \& Theses Global. (2158870695). Retrieved from https://search.proquest.com/docview/2158870695? accountid=25089.

Wallace, R. L. (2015). Grit and student performance: A mixed-method analysis of a nontraditional technical high school and a traditional high school (Order No. 10036393). Available from ProQuest Dissertations \& Theses Global. (1775742276).

Retrieved from https://search.proquest.com/docview/1775742276?accountid=25089. 
Azim Eğitim Programının Azim ve Motivasyonel Kararlılık Düzeylerine Etkisinin İncelenmesi

Yoncalık, O. (2018). Lise öğrencilerinde azim, mutluluk ve umutsuzluğun yaşam doyumları ve akademik başarlarına etkisi. Yayımlanmamış Yüksek Lisans Tezi. Gazi Üniversitesi Eğitim Bilimleri Enstitüsü.

\section{Kaynakça Bilgisi / Citation Information}

Ekinci, N. ve Hamarta, E. (2020). Azim eğitim programının azim ve motivasyonel kararlılık düzeylerine etkisinin incelenmesi. OPUSUluslararası Toplum Araştırmaları Dergisi, 16(28), 962-996. DOI: 10.26466/opus.691887 